\title{
An investigation into the effects of simulated ischaemic preconditioning on mitochondrial fusion in mouse embryonic fibroblasts
}

\author{
Ernest J Chew*, Andrew R Hall, Niall F Burke, Derek J Hausenloy, Derek Yellon \\ From World Society of Cardiothoracic Surgeons 25th Anniversary Congress, Edinburgh \\ Edinburgh, UK. 19-22 September 2015
}

\section{Background/Introduction}

Ischaemic conditioning is the cardioprotective process of exposing the heart to short periods of ischaemia and reperfusion in order to increase its survivability when encountered with a subsequent sustained period of lethal ischaemia. Mitochondria undergo fusion and fission processes and potentiating mitochondrial fission has been reported to be linked to increased cell death.

\section{Aims/Objectives}

Investigate if the beneficial effect of ischaemic preconditioning is mediated by mitochondrial fusion.

\section{Method}

Mouse embryonic fibroblasts (MEFs) were divided into three groups: (i) Normoxia, (ii) simulated ischaemiareperfusion injury (SIRI) and (iii) hypoxic pre-conditioned (Pre-con). Mitochondrial morphology was then determined using confocal imaging and cell death was assessed by flow cytometry.

\section{Results}

Cell death was $2.1 \% \pm 1.4 \%, 30 \% \pm 13.2 \%$ and $10 \% \pm$ $6.8 \%$ in Normoxia, SIRI and Pre-con groups respectively $(\mathrm{p}<0.0001)$. Mitochondria morphology studies showed that MEFs that underwent period of SIRI had a $46 \% \pm$ $6.1 \%$ decrease in fused mitochondria compared to normoxic controls. More importantly, MEFs which have undergone hypoxic pre-conditioning before the period of SIRI showed an increase in the amount of fused mitochondrial networks compared to MEFs which were exposed to SIRI only $(19.3 \% \pm 1.6$ vs $4.5 \% \pm 6.4 \%$

The Hatter Cardiovascular Institute, University College London, 67 Chenies Mews, London WC1E 6HX, UK respectively, $\mathrm{p}<0.05)$. However, Hypoxic pre-conditioning does not seem to be inducing mitochondrial fusion as MEFs exposed to the pre-conditioning protocol only, showed a $16 \% \pm 2.1 \%$ decrease in mitochondrial fusion.

\section{Discussion/Conclusion}

This study demonstrates that ischaemic pre-conditioning can be replicated in a cell line and that it appears to be preventing cell death by inhibiting mitochondrial fission. Further studies could are needed to investigate the effects of inhibiting different levels of the mitochondrial fission pathway in different cell line and animal models.

Published: 16 December 2015

\section{doi:10.1186/1749-8090-10-S1-A64}

Cite this article as: Chew et al:: An investigation into the effects of simulated ischaemic preconditioning on mitochondrial fusion in mouse embryonic fibroblasts. Journal of Cardiothoracic Surgery 2015 10(Suppl 1): A64.
Submit your next manuscript to BioMed Central and take full advantage of:

- Convenient online submission

- Thorough peer review

- No space constraints or color figure charges

- Immediate publication on acceptance

- Inclusion in PubMed, CAS, Scopus and Google Scholar

- Research which is freely available for redistribution 